原 著 論 文

\title{
頭位の側方傾斜が下顎位に及ぼす影響
}

\author{
中島 優, 小出 馨, 荒川いつか, 小出 勝義
}

\section{Influence of Lateral Head Tilt on Mandibular Position}

Yu Nakajima, DDS, PhD, Kaoru Koide, DDS, PhD, Itsuka Arakawa, DDS and Katsuyoshi Koide, DDS

\begin{abstract}
抄 録
目的 : 本研究では, 頭位の側方傾斜度を変化させた際の顆頭点および切歯点の三次元的位置を測定し, 頭 位の側方傾斜と下顎位の関連性を検討した。

方法：被験者は健常有歯顎者 30 名とし，上顎にはアンテリアジグを，下顎にはパラオクルーザルクラッ チを装着し, Win Jaw System ${ }^{\circledR}$ を用いて顆頭点と切歯点の位置を記録した。頭位の側方傾斜の条件は, $0^{\circ}$ と $5^{\circ}, 10^{\circ}, 15^{\circ}, 20^{\circ}, 25^{\circ}, 30^{\circ}$ 傾斜させた計 7 条件とした。各条件において, 頭位の側方傾斜によ る顆頭点の前後方向, 左右方向, 上下方向の偏位量および切歯点の前後方向, 左右方向の偏位量を測定し た．分析は，頭位の側方傾斜度による顆頭点および切歯点の偏位量の違いについて，反復測定による一元 配置分散分析を行い，その後 Bonferroni 法により多重比較検定を行った。

結果 : 頭位の側方傾斜により, 傾斜側顆頭点の偏位量は頭位の傾斜度が増すにつれて増加傾向を示した が，前後方向，左右方向，上下方向ともに有意差は認められなかった。非傾斜側顆頭点は頭位の傾斜度が 増すにつれて前下方へ偏位し， $10^{\circ}$ 以上の傾斜条件で基準との間に偏位量の差が認められた。切歯点は頭 位の傾斜度が増すにつれて傾斜側前方へ偏位し，10以上の傾斜条件で有意差が認められた。

結論 : 頭位の側方傾斜は下顎を傾斜側前方へ偏位させることが明らかとなり, 傾斜度の増加に伴い偏位量 が増す傾向が示唆された。
\end{abstract}

\section{和文キーワード}

頭位, 下顎位, 顆頭点, 切歯点, 三次元 6 自由度顎運動測定装置

\section{I. 緒言}

咬合が関与する歯科診療は坐位で行うことが有効で あるが，歯科診療ユニットのヘッドレストに頭部を固 定した姿勢で診療を行った際，坐位であっても患者が 日常生活を行う本来の下顎位とは異なる場合があり, 構成する咬合接触関係に影響を及ぼす可能性がある. 歯科診療を生理的に顎口腔系と調和した下顎位で行う ことは，患者の生活の質に繋がる重要な要素であり， 患者姿勢が下顎位に与える影響を明確にすることが必 要である.

下顎は，勒帯，関節包，咀嚼筋，皮膚などの軟組織
により吊り下げられた状態で位置を保っており ${ }^{1)}$ ，診 療時の患者の体位や頭位は, 下顎位 ${ }^{2-4)}$, 下顎運動 ${ }^{5)}$ お よび頭頸部筋群の筋活動 ${ }^{2-6)}$ に影響を及ぼすことが報告 されている。これまでに診療時の患者姿勢について, 体位を後方へ $30^{\circ}$ 以上傾斜した場合，また頭位を前方 あるいは後方へ $10^{\circ}$ 以上傾斜した場合に下顎位は偏位 することが明らかにされている ${ }^{2-4)}$ 。しかし，これらの 報告はへッドレストに頭部を固定した状態で行われて おり, 被験者本来の自然頭位とは異なることが推察さ れる。

本研究では, 頭位の側方傾斜が下顎位に与える影響 を明らかにすることを目的として，健常者を対象とし て頭位の側方傾斜度を段階的に変化させた際の顆頭点

日本歯科大学新潟生命歯学部歯科補綴学第 1 講座

Department of Removable Prosthodontics, The Nippon Dental University School of Life Dentistry at Niigata

受付 : 2014 年 1 月 6 日/受理 2014 年 3 月 14 日

Received on January 6, 2014/Accepted on March 14, 2014 


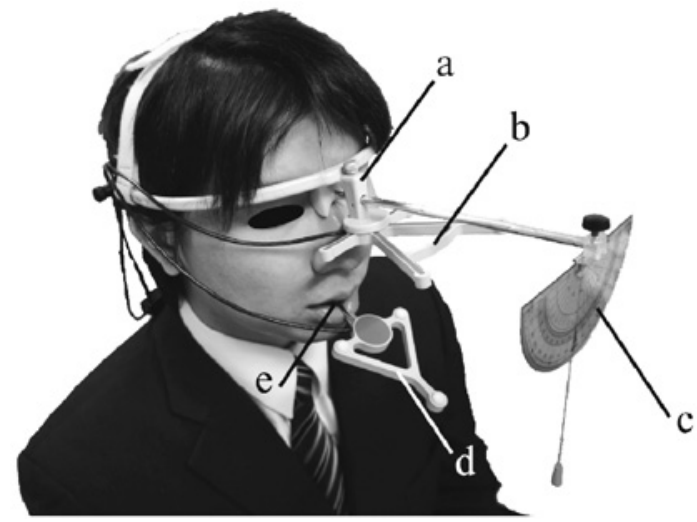

図 1 Measuring device (Win Jaw System ${ }^{\circledR}$ ) a: face bow b: sensor of receiver c: measuring device of lateral head tilt d: marker e: paraocclusal clutch 測定装置 (Win Jaw System ${ }^{\circledR}$ )

$\mathrm{a}$ : フェイスボウ $\mathrm{b}$ : レシーバーセンサー $c$ : 頭位側方傾斜度測定装置 $d:$ マ マーカー $\mathrm{e}$ : パラオクルーザルクラッチ

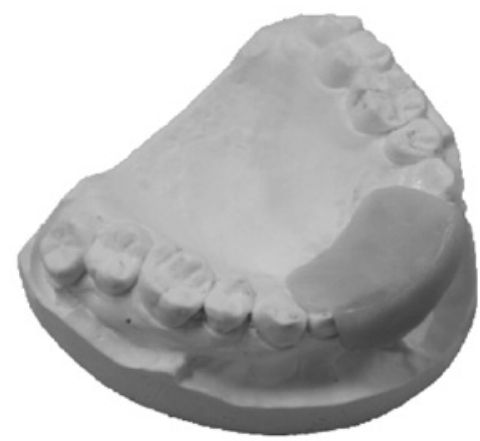

図 2 Anterior jig アンテリアジグ

および切歯点の偏位量を測定し，頭位の側方傾斜と下 顎位の関連性について検討を行った。

\section{II. 研究方法}

\section{1、被験者}

被験者は，個性正常咬合を有し顎口腔系に機能異常 を認めない健常有歯顎者 30 名 (男性 19 名, 女性 11 名, 平均年齢 $24.3 \pm 1.5$ 歳）である。なお，本研究は日本 歯科大学新潟生命歯学部倫理委員会の承認を得て（承 認番号; ECNG-H-83), 被験者には研究の趣旨を十分 に説明し，同意を得た上で開始した。

\section{2. 測定装置}

顆頭点および切歯点の測定には，三次元 6 自由度顎

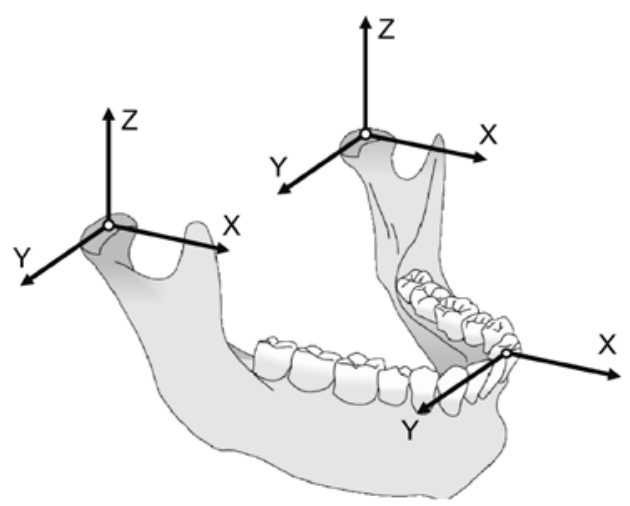

図 3 Measurement direction and measurement point X-axis: anteroposterior shift (anterior; +, posterior; -) Y-axis: horizontal shift (flexed side; +, extended side; -) Z-axis: vertical shift (upper part; +, lower part; -) 測定点と測定方向

$\mathrm{X}$ 軸 : 前後方向 (前方 $;+$, 後方 $;-$ )

$\mathrm{Y}$ 軸: 左右方向 (傾斜側方向; + , 非傾斜側方向 ; - ) $\mathrm{Z}$ 軸：上下方向（上方； + , 下方 $;-$ ）

運動測定装置（Win Jaw System ${ }^{\circledR}$, zebris, Aachen,

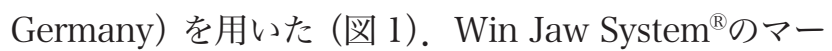
カーを固定したパラオクルーザルクラッチは常温重合 レジン (パターンレジン ${ }^{\circledR}$, ジーシー, 東京, 日本) を 用いて製作し,カルボキシレートセメント（ハイボンド テンポラリーセメントハード ${ }^{\circledR}$ ，松風，京都，日本）に より下顎歯列唇煩側面に固着した。また，咬合器に装 着した上下顎模型上で，常温重合レジン（トレーレジ ン ${ }^{\circledR}$ ，松風）を用いてアンテリアジグを製作し（図 2), 西巻ら ${ }^{2)}$ の方法に従って, アンテリアジグ表面に自然頭 位で得られたタッピングポイントの周囲約 $3 \mathrm{~mm}$ の範 囲に咬合平面と平行な平面を設定した。なお,アンテリ アジグの咬合挙上量は $3 \mathrm{~mm}$ 未満とした.

\section{3. 測定方法}

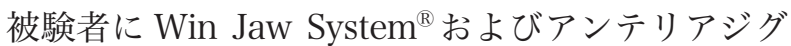
を装着し，アッパーフェイスボウ前方部には頭位側方 傾斜度測定装置を装着した ${ }^{4)}$ 。被験者の姿勢は坐位と し，背もたれに寄りかからない状態で太田ら ${ }^{7)}$ の方法 に従って頭位は固定せずに自然頭位をとらせた。自然 頭位において頭位側方傾斜度測定装置の角度を $0^{\circ}$ と なるように調整し，2 秒間に 3 回の速度で開口量約 $10 \mathrm{~mm}$ のタッピング運動を 20 回以上行わせ, タッピ ングポイントが収束したことを確認し，この時の左右 側顆頭点と切歯点の位置を基準位とした ${ }^{4)}$ 。なお，本 研究における顆頭点は, 左右側の Beyron's point を結 ぶ軸長の内側 $68.4 \%$ の位置に相当する点とし ${ }^{8}$, 切歯 
表 1 Results of the one-way ANOVA with a Greenhouse-Geisser correction in shift of X-axis direction of condylar point $\mathrm{a}$ : condylar point on the side of the flexed neck b: condylar point on the side of the extended neck 顆頭点の X軸方向の偏位量における一元配置分散分析の結果 $a$ : 傾斜側顆頭点 $b$ : 非傾斜側顆頭点

表 1 a

\begin{tabular}{lrrccc}
\hline Source & \multicolumn{1}{c}{$d f$} & \multicolumn{1}{c}{ SS } & MS & $F$ value & $p$ value \\
\hline Head tilt angle & 2.498 & 0.309 & 0.124 & 0.978 & 0.396 \\
Residual & 72.446 & 9.176 & 0.127 & & \\
Total & 210.000 & 36.437 & & & \\
\hline
\end{tabular}

df: degree of freedom. SS: sum of squares. MS: mean square.

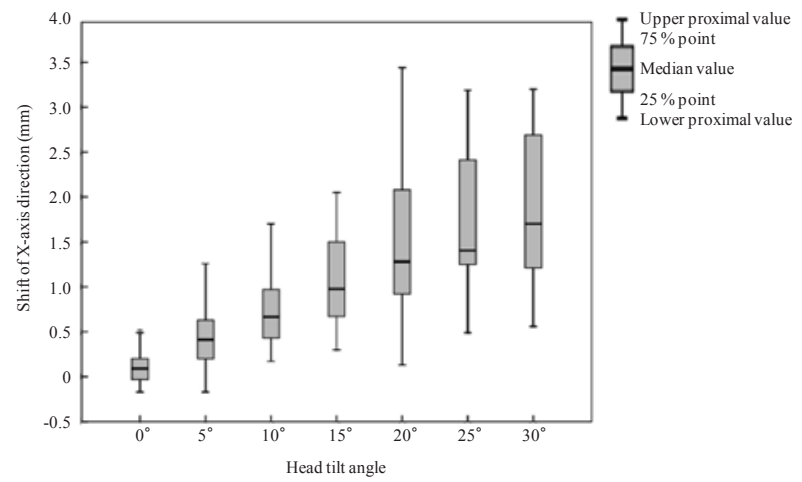

図 4 Result of multiple comparison tests in shift of $\mathrm{X}$-axis direction of condylar point on the side of the extended neck 非傾斜側顆頭点の X 軸方向の偏位量における多重比 較検定の結果

点は下顎左右側中切歯近心隅角の中点とした。

頭位の傾斜条件は, 自然頭位である $0^{\circ}$ から側方へ $5^{\circ}$, $10^{\circ}, 15^{\circ}, 20^{\circ}, 25^{\circ}, 30^{\circ}$ 傾斜させた計 7 条件とした。 なお, 本研究の対象者は顎口腔系に機能異常を認めな い健常者を選択したため，傾斜側は左右側 15 例ずつ とし，各傾斜条件における測定順序はランダムとした。 各条件において，1 回の測定につき開口量約 $10 \mathrm{~mm}$ のタッピングを 10 回行った際の傾斜側顆頭点, 非傾 斜側顆頭点および切歯点の座標デー夕を記録し，平均 值を求めた。 顆頭点は, 前後方向を示す X 軸 $($ 前方; + , 後方 $;-$ ), 左右方向を示す Y 軸（傾斜側方向 $;+$, 非 傾斜側方向 ；-)，上下方向を示す Z 軸（上方；+，下 方；-）について，切歯点は前後方向を示す X軸，左 右方向を示す Y 軸について解析を行った（図 3)。測 定は各条件 3 回ずつ行い, 平均值を分析に用い, それ ぞれ 30 組の記録を分析に用いた。

\section{4. 分析方法}

統計解析は，統計処理ソフト (SPSS 17.0, SPSS
表 1 b

\begin{tabular}{lrrrrc}
\hline Source & \multicolumn{1}{c}{$d f$} & \multicolumn{1}{c}{ SS } & \multicolumn{1}{c}{ MS } & $F$ value & $p$ value \\
\hline Head tilt angle & 1.852 & 89.060 & 48.100 & 53.734 & $<0.001^{* *}$ \\
Residual & 53.695 & 48.065 & 0.895 & & \\
Total & 210.000 & 488.697 & & & \\
\hline
\end{tabular}

$d f$ : degree of freedom. SS: sum of squares. MS: mean square.

${ }^{* *} p<0.01$ : denotes statistically significant difference.

表 2 Result of multiple comparison tests in shift of $\mathrm{X}$-axis direction of condylar point on the side of the extended neck

非傾斜側顆頭点の X 軸方向の偏位量における多重比 較検定の結果

\begin{tabular}{rrrrrrrr}
\hline & $0^{\circ}$ & $5^{\circ}$ & $10^{\circ}$ & $15^{\circ}$ & $20^{\circ}$ & $25^{\circ}$ & $30^{\circ}$ \\
\hline $0^{\circ}$ & & & & & & & \\
$5^{\circ}$ & n.s. & & & & & & \\
$10^{\circ}$ & n.s. & n.s. & & & & \\
$15^{\circ}$ & $* *$ & n.s. & n.s. & & & \\
$20^{\circ}$ & $* *$ & $* *$ & n.s. & n.s. & & \\
$25^{\circ}$ & $* *$ & $* *$ & $* *$ & n.s. & n.s. & \\
$30^{\circ}$ & $* *$ & $* *$ & $* *$ & $* *$ & n.s. & n.s. \\
\hline & & & & & $* * p<0.01$, n.s.: not significant
\end{tabular}

JAPAN，東京，日本）を用いて行った．頭位の側方傾 斜度による傾斜側顆頭点と非傾斜側顆頭点の $\mathrm{X}$ 軸， $\mathrm{Y}$ 軸， $\mathrm{Z}$ 軸方向の偏位量，および切歯点の $\mathrm{X}$ 軸， $\mathrm{Y}$ 軸 方向の偏位量の違いについて分析を行った。正規性の 検定には Shapiro-Wilk 検定を，等分散性の検定には Mauchly の球形検定を用いた。正規性は認められた が，等分散性は認められなかったため，GreenhouseGeisser の $\varepsilon$ 修正を行い，反復測定による一元配置分 散分析を行った。その後, 有意差の認められた要因に おいて, Bonferroni 法により多重比較検定を行った。 いずれも危険率 $5 \%$ 未満を有意とし，検出力は 0.8 に 設定した。

\section{III. 結果}

1. 顆頭点の偏位について

1) 顆頭点の X 軸方向の偏位量

表 1 に顆頭点の X 軸方向の偏位量における一元配置 分散分析の結果を示す。傾斜側顆頭点では頭位の側方 傾斜度による偏位量に有意差は認められなかったが, 非傾斜側顆頭点では有意差が認められた。

図 4 と表 2 に非傾斜側顆頭点の X 軸方向の偏位量に 
表 3 Results of the one-way ANOVA with a Greenhouse-Geisser correction in shift of Y-axis direction of condylar point a: condylar point on the side of the flexed neck b: condylar point on the side of the extended neck 顆頭点のY 軸方向の偏位量における一元配置分散分析の結果 $a$ : 傾斜側顆頭点 $b$ ：非傾斜側顆頭点

表 3 a

\begin{tabular}{lrrccc}
\hline Source & \multicolumn{1}{c}{$d f$} & \multicolumn{1}{c}{ SS } & MS & $F$ value & $p$ value \\
\hline Head tilt angle & 1.545 & 9.144 & 5.918 & 33.151 & $<0.001^{* *}$ \\
Residual & 44.810 & 7.999 & 0.179 & & \\
Total & 210.000 & 85.754 & & & \\
\hline
\end{tabular}

$d f$ : degree of freedom. SS: sum of squares. MS: mean square.

${ }^{* *} p<0.01$ : denotes statistically significant difference.

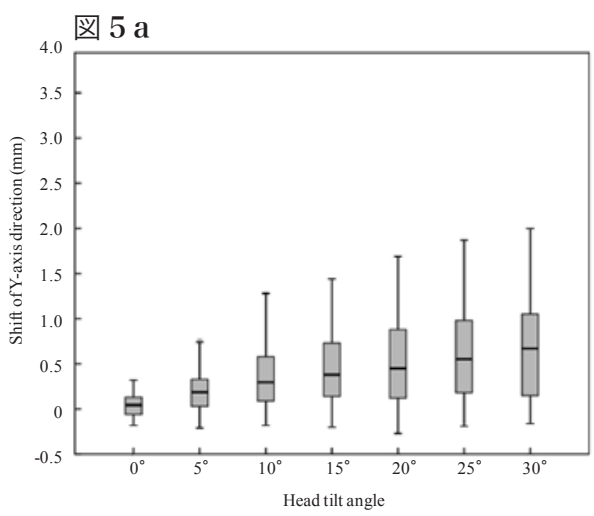

表 $3 \mathrm{~b}$

\begin{tabular}{lrrccc}
\hline Source & \multicolumn{1}{c}{$d f$} & \multicolumn{1}{c}{ SS } & MS & $F$ value & $p$ value \\
\hline Head tilt angle & 1.566 & 11.058 & 7.062 & 39.315 & $<0.001^{* *}$ \\
Residual & 45.410 & 8.157 & 0.180 & & \\
Total & 210.000 & 95.365 & & & \\
\hline
\end{tabular}

$d f$ : degree of freedom. SS: sum of squares. MS: mean square.

$*_{*}^{*} p<0.01$ : denotes statistically significant difference.

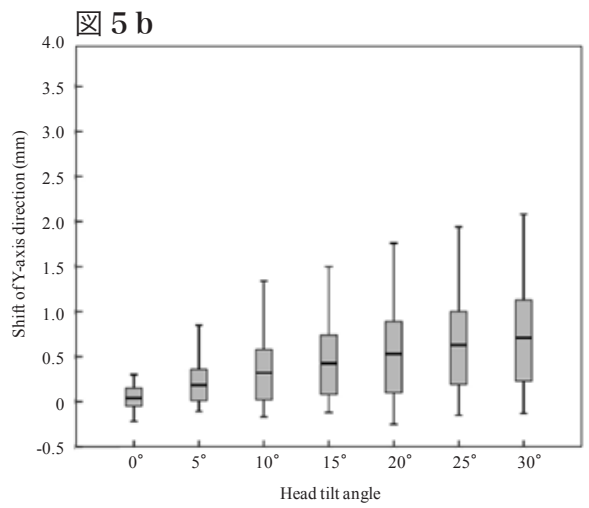

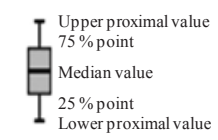

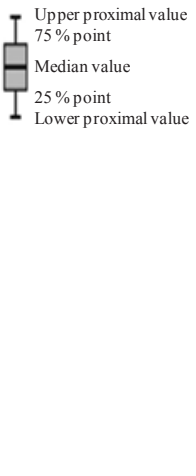

図 5 Result of multiple comparison tests in shift of Y-axis direction of condylar point a: condylar point on the side of the flexed neck b: condylar point on the side of the extended neck 顆頭点の Y 軸方向の偏位量における多重比較検定の結果 $\mathrm{a}$ : 傾斜側顆頭点の偏位量 $\mathrm{b}$ : 非傾斜側顆頭点の偏位量

表 4 Result of multiple comparison tests in shift of Y-axis direction of condylar point a: condylar point on the side of the flexed neck b: condylar point on the side of the extended neck 顆頭点の Y 軸方向の偏位量における多重比較検定の結果 $\mathrm{a}$ ：傾斜側顆頭点の偏位量 $\mathrm{b}$ ：非傾斜側顆頭点の偏位量

表 $4 \mathrm{a}$

\begin{tabular}{rlllllll}
\hline & $0^{\circ}$ & $5^{\circ}$ & $10^{\circ}$ & $15^{\circ}$ & $20^{\circ}$ & $25^{\circ}$ & $30^{\circ}$ \\
\hline $0^{\circ}$ & & & & & & & \\
$5^{\circ}$ & n.s. & & & & & & \\
$10^{\circ}$ & n.s. & n.s. & & & & \\
$15^{\circ}$ & n.s. & n.s. & n.s. & & & \\
$20^{\circ}$ & n.s. & n.s. & n.s. & n.s. & & \\
$25^{\circ}$ & n.s. & n.s. & n.s. & n.s. & n.s. & \\
$30^{\circ}$ & n.s. & n.s. & n.s. & n.s. & n.s. & n.s. \\
\hline & & & & & & n.s.: not significant
\end{tabular}

おける多重比較検定の結果を示す。非傾斜側顆頭点の 偏位量は $0^{\circ}$ と $15^{\circ}$ 以上の傾斜条件の間で有意差が認め られ，傾斜度が増すにつれて増加する傾向を示した。

2）顆頭点の Y 軸方向の偏位量

表 3 に顆頭点の $\mathrm{Y}$ 軸方向の偏位量における一元配置 分散分析の結果を示す。傾斜側顆頭点, 非傾斜側顆頭 点において，頭位の側方傾斜度による偏位量に有意差
表 $4 \mathrm{~b}$

\begin{tabular}{rlllllll}
\hline & $0^{\circ}$ & $5^{\circ}$ & $10^{\circ}$ & $15^{\circ}$ & $20^{\circ}$ & $25^{\circ}$ & $30^{\circ}$ \\
\hline $0^{\circ}$ & & & & & & & \\
$5^{\circ}$ & n.s. & & & & & & \\
$10^{\circ}$ & n.s. & n.s. & & & & \\
$15^{\circ}$ & n.s. & n.s. & n.s. & & & \\
$20^{\circ}$ & n.s. & n.s. & n.s. & n.s. & & \\
$25^{\circ}$ & n.s. & n.s. & n.s. & n.s. & n.s. & \\
$30^{\circ}$ & n.s. & n.s. & n.s. & n.s. & n.s. & n.s. \\
\hline & & & & & & \multicolumn{2}{c}{ n.s.: not significant }
\end{tabular}

が認められた。

図 5 と表 4 に顆頭点の $\mathrm{Y}$ 軸方向の偏位量における多 重比較検定の結果を示す。傾斜側顆頭点, 非傾斜側顆 頭点の偏位量に有意差は認められなかったが，傾斜度 が増すにつれて増加する傾向を示した。

3）顆頭点の Z 軸方向の偏位量

表 5 に顆頭点の Z 軸方向の偏位量における一元配置 
表 5 Results of the one-way ANOVA with a Greenhouse-Geisser correction in shift of Z-axis direction of condylar point a: condylar point on the side of the flexed neck b: condylar point on the side of the extended neck 顆頭点の Z 軸方向の偏位量における一元配置分散分析の結果

$\mathrm{a}$ ：傾斜側顆頭点 $\quad b$ ：非傾斜側顆頭点

表 5 a

\begin{tabular}{lrrccc}
\hline Source & \multicolumn{1}{c}{$d f$} & \multicolumn{1}{c}{ SS } & MS & $F$ value & $p$ value \\
\hline Head tilt angle & 2.285 & 0.978 & 0.428 & 1.741 & 0.179 \\
Residual & 66.257 & 16.295 & 0.246 & & \\
Total & 210.000 & 57.753 & & & \\
\hline
\end{tabular}

$d f$ : degree of freedom. SS: sum of squares. MS: mean square.

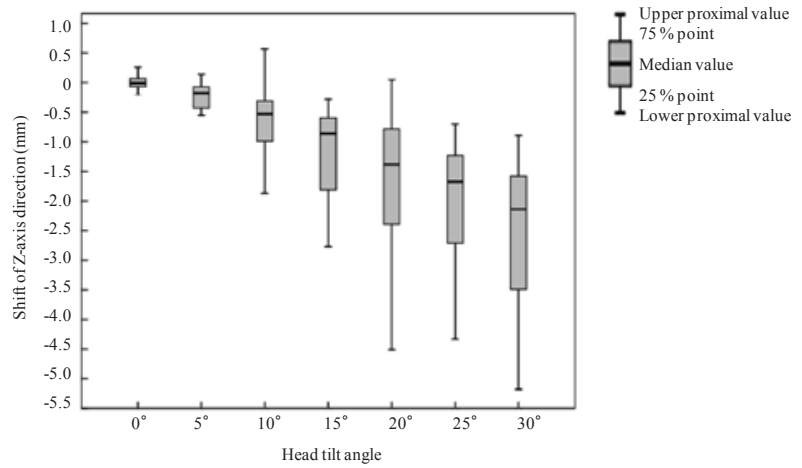

図 6 Result of multiple comparison tests in shift of Z-axis direction of condylar point a: condylar point on the side of the flexed neck b: condylar point on the side of the extended neck 非傾斜側顆頭点の Z 軸方向の偏位量における多重 比較検定の結果

分散分析の結果を示す．傾斜側顆頭点では頭位の側方 傾斜度による偏位量に有意差は認められなかったが, 非傾斜側顆頭点では有意差が認められた。

図 6 と表 6 に非傾斜側顆頭点の Z 軸方向の偏位量に おける多重比較検定の結果を示す。非傾斜側顆頭点の 偏位量は $0^{\circ}$ と $10^{\circ}$ 以上の傾斜条件の間で有意差が認め られ，傾斜度が増すにつれて増加する傾向を示した。

\section{2. 切歯点の偏位について}

表 7 に切歯点の X 軸方向, $\mathrm{Y}$ 軸方向の偏位量におけ る一元配置分散分析の結果を示す。頭位の側方傾斜度 による切歯点の偏位量には X 軸方向, Y 軸方向とも有 意差が認められた。

図 7 と表 8 に切歯点の X 軸方向, Y 軸方向の偏位量 における多重比較検定の結果を示す，X軸方向の偏位 量は $0^{\circ}$ と $20^{\circ}$ 以上の傾斜条件の間で，Y 軸方向の偏位 量は $0^{\circ}$ と $10^{\circ}$ 以上の傾斜条件の間で有意差が認められ, 傾斜度が増すにつれて増加する傾向を示した。
表 $5 \mathrm{~b}$

\begin{tabular}{lrrrrr}
\hline Source & \multicolumn{1}{c}{$d f$} & \multicolumn{1}{c}{ SS } & \multicolumn{1}{c}{ MS } & $F$ value & $p$ value \\
\hline Head tilt angle & 2.217 & 147.233 & 66.411 & 73.422 & $<0.001^{* *}$ \\
Residual & 64.293 & 58.154 & 0.905 & & \\
Total & 210.000 & 621.652 & & & \\
\hline
\end{tabular}

$d f:$ degree of freedom. SS: sum of squares. MS: mean square.

${ }^{* *} p<0.01$ : denotes statistically significant difference.

表 6 Result of multiple comparison tests in shift of Z-axis direction of condylar point on the side of the extended neck 非傾斜側顆頭点の Z 軸方向の偏位量における多重比 較検定の結果

\begin{tabular}{|c|c|c|c|c|c|c|c|}
\hline & $0^{\circ}$ & $5^{\circ}$ & $10^{\circ}$ & $15^{\circ}$ & $20^{\circ}$ & $25^{\circ}$ & $30^{\circ}$ \\
\hline $0^{\circ}$ & & & & & & & \\
\hline $5^{\circ}$ & n.s. & & & & & & \\
\hline $10^{\circ}$ & * & n.s. & & & & & \\
\hline $15^{\circ}$ & $* *$ & $* *$ & n.s. & & & & \\
\hline $20^{\circ}$ & $* *$ & $* *$ & $* *$ & n.s. & & & \\
\hline $25^{\circ}$ & $* *$ & $* *$ & $* *$ & $* *$ & n.s. & & \\
\hline $30^{\circ}$ & $* *$ & $* *$ & ** & $* *$ & $*$ & n.s. & \\
\hline
\end{tabular}

\section{IV. 考 察}

\section{1. 測定装置について}

Win Jaw System ${ }^{\circledR}$ は超音波を用いた三次元 6 自由度 顎運動測定装置であり，顆頭点と切歯点の微小な偏位 量を同時に測定することが可能である ${ }^{9-15)}$ 。 下顎に装着 するマーカーの重量は $55 \mathrm{~g}$ と軽量であるため, 測定值 に及ぼす影響は少ないと考える。 また, 非接触式測定 装置であるため, 力学的抵抗による下顎偏位量の影響 が生じることなく測定を行える点で，接触式測定装置 と比較して有利である。

本研究において，頭位の側方傾斜による測定装置の 動摇を抑制するため，アッパーフェイスボウに独自に 製作したへッドバンドを組み込み安定性の向上を図っ た。また，上下顎歯列の接触感覚が下顎の偏位に及ぼ す影響を可及的に抑制することを目的として，アンテ リアジグを製作した。このアンテリアジグは，可及的 に安静空隙を越えない範囲の最小咬合挙上量で，舌房 も可及的に阻害せず，下顎両側中切歯切縁のみ接触す るように製作した。咬合高径の挙上による下顎位への 影響に関して, 咬合挙上量が切歯点で $3 \mathrm{~mm}$ 未満であ 
表 7 Results of the one-way ANOVA with a Greenhouse-Geisser correction in shift of incisal points a: Shift of $\mathrm{X}$-axis direction b: Shift of Y-axis direction 切歯点の偏位量における一元配置分散分析の結果 $a ： X$ 軸方向 $b ： Y$ 軸方向

表 7 a

\begin{tabular}{lrrrrc}
\hline Source & $d f$ & \multicolumn{1}{c}{ SS } & \multicolumn{1}{c}{ MS } & $F$ value & $p$ value \\
\hline Head tilt angle & 2.101 & 41.418 & 19.717 & 38.378 & $<0.001^{* *}$ \\
Residual & 60.916 & 31.296 & 0.514 & & \\
Total & 210.000 & 257.324 & & & \\
\hline
\end{tabular}

$d f$ : degree of freedom. SS: sum of squares. MS: mean square. $*^{*} p<0.01$ : denotes statistically significant difference.
表 7 b

\begin{tabular}{lrrrrc}
\hline Source & \multicolumn{1}{c}{$d f$} & \multicolumn{1}{c}{ SS } & \multicolumn{1}{c}{ MS } & $F$ value & $p$ value \\
\hline Head tilt angle & 1.971 & 287.331 & 145.795 & 88.939 & $<0.001^{* *}$ \\
Residual & 57.153 & 93.688 & 1.639 & & \\
Total & 210.000 & 1307.236 & & & \\
\hline
\end{tabular}

$d f$ : degree of freedom. SS: sum of squares. MS: mean square. ${ }^{* *} p<0.01$ : denotes statistically significant difference.
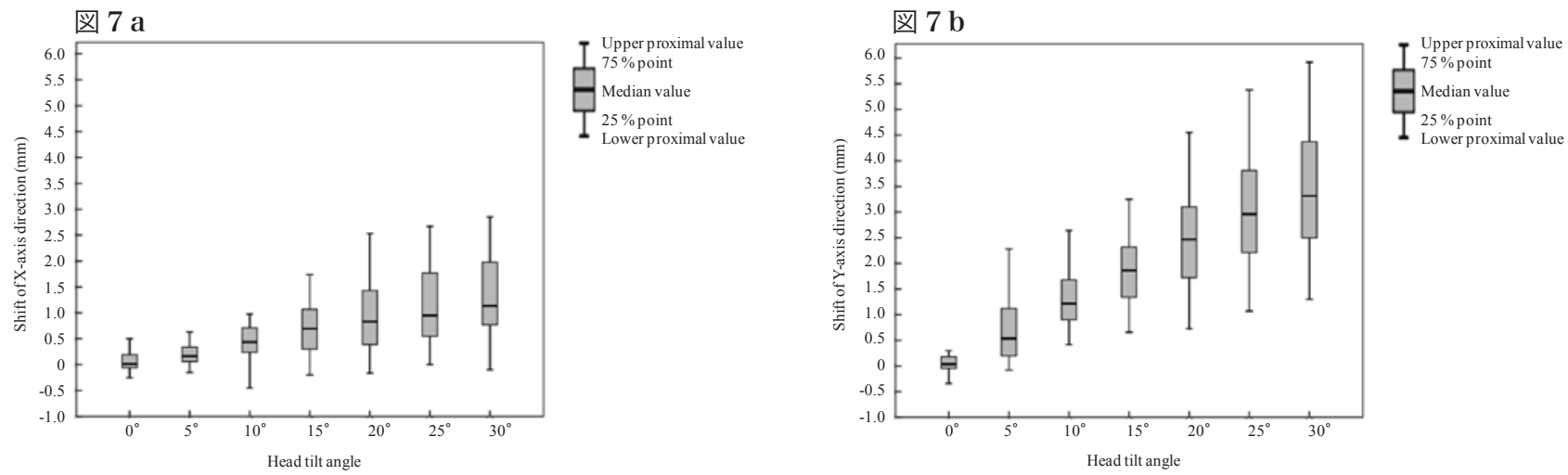

図 7 Result of multiple comparison tests in shift of incisal points

a: Shift of X-axis direction b: Shift of Y-axis direction

切歯点の偏位量における多重比較検定の結果

$a: X$ 軸方向の偏位量 $b$ : Y 軸方向の偏位量

表 8 Result of multiple comparison tests in shift of incisal points

a: Shift of X-axis direction b: Shift of Y-axis direction

切歯点の偏位量における多重比較検定の結果

$a ： X$ 軸方向の偏位量 $b: Y$ 軸方向の偏位量

表 8 a

\begin{tabular}{rrrrrrrr}
\hline & $0^{\circ}$ & $5^{\circ}$ & $10^{\circ}$ & $15^{\circ}$ & $20^{\circ}$ & $25^{\circ}$ & $30^{\circ}$ \\
\hline $0^{\circ}$ & & & & & & \\
$5^{\circ}$ & n.s. & & & & & \\
$10^{\circ}$ & n.s. & n.s. & & & & \\
$15^{\circ}$ & n.s. & n.s. & n.s. & & & \\
$20^{\circ}$ & $* *$ & $* *$ & n.s. & n.s. & & \\
$25^{\circ}$ & $* *$ & $* *$ & n.s. & n.s. & n.s. & \\
$30^{\circ}$ & $* *$ & $* *$ & $* *$ & n.s. & n.s. $\quad$ n.s. \\
\hline & & & & $* * * p<0.01$, n.s.: not significant
\end{tabular}

れば，タッピング時の前後的，左右的分布はいずれも 小さい範囲に収束することが報告されている ${ }^{16,17)}$ 。こ のため，本研究ではすべての被験者において咬合挙上 量は $3 \mathrm{~mm}$ 未満とし，違和感を覚える不自然な咬合高 径でないことを確認した後に測定を行ったため，咬合 挙上による測定結果への影響は最小限に抑制できたと
表 $8 \mathrm{~b}$

\begin{tabular}{|c|c|c|c|c|c|c|c|}
\hline & $0^{\circ}$ & $5^{\circ}$ & $10^{\circ}$ & $15^{\circ}$ & $20^{\circ}$ & $25^{\circ}$ & $30^{\circ}$ \\
\hline $0^{\circ}$ & & & & & & & \\
\hline $5^{\circ}$ & n.s. & & & & & & \\
\hline $10^{\circ}$ & $* *$ & n.s. & & & & & \\
\hline $15^{\circ}$ & $* *$ & $* *$ & n.s. & & & & \\
\hline $20^{\circ}$ & $* *$ & $* *$ & $* *$ & n.s. & & & \\
\hline $25^{\circ}$ & $* *$ & $* *$ & $* *$ & $* *$ & n.s. & & \\
\hline $30^{\circ}$ & $* *$ & $* *$ & $* *$ & $* *$ & * & n.s. & \\
\hline
\end{tabular}

考える。

\section{2. 測定条件について}

本研究における下顎位の記録は，臨床において広く 用いられている簡便なタッピングによる方法を選択 し, 西巻ら ${ }^{2)}$ の方法に従って, 2 秒間に 3 回の速度で 
開口量約 $10 \mathrm{~mm}$ の軽いタッピング運動を行うように 指示した。その際，表情筋の緊張による下顎の後方偏 位を抑制するよう配慮した。したがって, 本研究でタッ ピングにより求めた下顎位は, 筋肉位として適当で再 現性の高い下顎位であると考える。また，タッピング 時の力について，0.6 kgf 以下の弱い力でのタッピング 運動が前後的に咬頭嵌合位と近似した位置に収束する ことが報告されており ${ }^{18)}$, 本研究においてもタッピン グ運動は噛み締めることのない軽いタッピングを行う よう指示した。

測定時の被験者の姿勢に関して，頭部をへッドレス トに固定した際には，姿勢維持筋の影響が軽減される ことが報告されている ${ }^{19)}$ 。このことから，側方傾斜し た位置で頭部を固定した場合は，本来の側方傾斜時の 状態と異なることが予測され，下顎位の偏位量にも影 響することが考えられる。したがって，本研究におい てはへッドレスト等による頭部の固定は行わず，頭位 傾斜度の設定をより正確に行うことを目的として，佐 藤ら ${ }^{4)}$ の方法を参考にアッパーフェイスボウ前方部に 頭位側方傾斜度測定装置を装着し，被験者と測定者 の双方で頭位側方傾斜度を確認した状態で測定を行つ た。

本研究における顆頭点は, 耳珠後縁の上下的中間点 から外眼角方向へ $13 \mathrm{~mm}$ の皮膚面上に求めた左右側 の Beyron's point を結ぶ軸長の内側 $68.4 \%$ の位置に 相当する点とした ${ }^{8}$. この測定点は実際の顆頭点に近 似しており，皮膚面上で求めた顆頭点と比較してょり 正確に偏位量を記録でき，また対側の顆頭点の動きに よる影響を最小限に抑制することができると考えられ る.

頭位の側方傾斜による下顎位への影響に関しては, 頭位を $30^{\circ}$ 側方傾斜させた際に開口位は偏位すること が報告されている ${ }^{20)}$.このことから，頭位の側方傾斜 は閉口時やタッピング時の下顎位にも影響することが 予測され，その影響を把握し，咬合治療時の患者姿勢 に配慮することは重要であると考える。したがって, 本研究における頭位の傾斜条件は, $0^{\circ}$ に対して, 側方 へ $5^{\circ}, 10^{\circ}, 15^{\circ}, 20^{\circ}, 25^{\circ}, 30^{\circ}$ 傾斜させた条件とした.

\section{3. 結果について}

頭位を側方傾斜させると, 傾斜側顆頭点は回転運動 の様相を呈し, 非傾斜側顆頭点は傾斜度が増すにつれ て傾斜側前下方へ漸次偏位した。 また, 切歯点は頭位 の傾斜度が増すにつれて傾斜側前方へ漸次偏位する傾 向を示した．統計学的有意差は頭位の傾斜 $10^{\circ}$ 以上の 条件で認められたが，非傾斜側顆頭点の X 軸方向の偏
位量は $5^{\circ}$ の条件で平均約 $0.4 \mathrm{~mm}$ と日常臨床におけ る下顎の偏位量として大きく, 今後さらに被験者数を 増やしより詳細に検討を行う必要があると考える。ま た，頭位の側方傾斜による下顎偏位については，下顎 へ加わる重力の方向 ${ }^{20)}$ が影響していることが予測され る. 頭位の側方傾斜度の増加に伴い, 下顎に対して重 力の加わる方向が傾斜側方向へ変化したため, 傾斜側 方向への下顎の偏位が引き起こされたものと考えられ る. 頭位の変化により緊張性頸反射や緊張性迷路反射

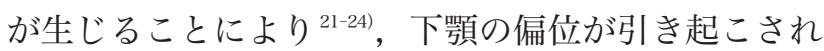
る可能性が推察されるが, 本研究では被験者にタッピ ング運動を行わせており，このような負荷を加えた条 件下では姿勢反射を超越して咀嚼筋が機能するという 報告 ${ }^{25)}$ や，随意運動が反射活動に優先して生じるとの 報告 ${ }^{26)}$ があることから, 本研究の測定に際しては, 緊 張性頸反射や緊張性迷路反射が下顎偏位を引き起こし た可能性は低いと考える。また，側方頭位では傾斜側 外側翼突筋下頭と非傾斜側側頭筋後部の筋活動が左右 協調性に生じることが報告されており ${ }^{20)}$, 本研究で示 された頭位の側方傾斜による下顎偏位は，下顎に加わ る重力だけでなく頭頸部筋の左右協調性の筋活動も影 響しているものと考える.

頭位を $30^{\circ}$ 側方傾斜した際，X軸方向の偏位量は切 歯点で約 $1.4 \mathrm{~mm}$ 程度であったが, 非傾斜側顆頭点で は約 $2.0 \mathrm{~mm}$ の偏位が認められた。切歯点の偏位量が 非傾斜側顆頭点の偏位量と比べて小さかったのは，Y 軸における傾斜側顆頭点の偏位量が約 $0.7 \mathrm{~mm}$ と小さ く, 下顎が水平面上で傾斜側顆頭点を中心とした回転 運動の様相を呈することに由来し, 非傾斜側顆頭点の $\mathrm{X}$ 軸方向の偏位が切歯点の X 軸方向よりも Y 軸方向の 偏位として大きく現れたためであると考えられる。ま た, 本研究では顆頭点を左右の Beyron's point を結ぶ 軸長の内側 $68.4 \%$ としたことから ${ }^{8)}$, 左右の顆頭点と 切歯点からなる三角形は顆頭間距離の短い二等辺三角 形となっているため, 頭位の側方傾斜度が $30^{\circ}$ の場合 に非傾斜側顆頭点の $X$ 軸方向は約 $2.0 \mathrm{~mm}$ 偏位し, 切 歯点で $\mathrm{Y}$ 軸方向に約 $3.5 \mathrm{~mm}$ と大きな偏位量を示した ものと考える. 本研究では自然頭位を基準位 $\left(0^{\circ}\right)$ と し, 測定值は 1 回の測定につきタッピングを 10 回行 い, 測定回数 3 回の座標データの平均值により求めた. $0^{\circ}$ の顆頭点, 切歯点のデー夕はともに個体差が大きく, 平均值が $0 \mathrm{~mm}$ を示さなかった。 今後, 被験者数をさ らに増やし検討を行う予定である。

以上のことから, 頭位を側方傾斜させると下顎は傾 斜側方向へ偏位しながら傾斜側の顆頭点を中心に回転 移動し，非傾斜側顆頭点は前下方へ偏位を示すことが 
明らかとなった。そして, $10^{\circ}$ 程度の頭位の側方傾斜 は下顎を有意に偏位させるため，咬合採得や咬合調整 などの咬合が関与する診療時には，頭位の側方傾斜に 十分配慮し, 患者固有の自然頭位で治療を行う必要が あることが示唆された。 また，本研究は頭位の側方傾 斜が下顎位に及ぼす影響について検討を行ったが，頭 位が傾斜している患者は側方傾斜だけでなく旋回を伴 う場合が見受けられるため，今後は頭位の旋回と下顎 位との関係について検討を加える予定である。

\section{V. 結 論}

三次元 6 自由度顎運動測定装置 Win Jaw System を用いて頭位の側方傾斜がタッピング運動時の顆頭点 および切歯点の偏位量に及ぼす影響を検討し, 以下の 結論を得た。

1. 頭位を側方傾斜させると傾斜側顆頭点は回転運動

し, 非傾斜側顆頭点は傾斜側前下方へ偏位し， $10^{\circ}$ 以上の傾斜条件で基準との間に偏位量の差が認めら れた。

2. 頭位の側方傾斜により切歯点は傾斜側前方へ偏位 し， $10^{\circ}$ 以上の傾斜条件で有意差が認められた。

\section{文献}

1）阿部伸一, 井出吉信, 小出 馨, 佐藤利英, 浅野栄一郎, 渡辺正宜. 顎関節の機能解剖。井出吉信, 小出 馨編, チェアサイドで行う顎機能診査のための基本機能解剖, 東京 : 医歯薬出版 ; 2012, 109-163.

2）西巻 仁, 小出 馨, 植木 誠, 浅沼直樹, 齊藤隆哉. 歯科治療時の体位による下顎位の変化に関する臨床的 研究. 補綴誌 $2002 ; 46: 64-72$.

3) Ishii M, Koide K, Ueki M, Asanuma N. Influence of body and head posture on deviation of the incisal point undergoing dental treatment. Prosthodont Res Pract 2007; 6: 217-224.

4）佐藤三幸, 小出 馨, 石井麻水, 佐藤利英。坐位におけ る頭位の前後的変化が顆頭点の偏位に及ぼす影響. 日補 綴会誌 $2012 ； 4: 277-285$.

5）池田圭介, 河野正司, 土田幸弘，松山剛士，大竹博之. 顆頭安定位の立場からみたタッピング運動時による水 平的下顎位の検索。補綴誌 $1996 ; 40: 964-971$.

6）関根和教, 今井貴夫, 立花文寿, 松田和徳, 佐藤 豪, 武田憲昭。咀嚼によりめまいが誘発された Costen 症候 群症例. Equilibrium Res $2010 ; 69: 47-51$.

7）太田敦子, 石上也澄志, 小出 馨, 旗手 敏, 小島 隆, 津川 克ほか. 補綴学的水平基準面に関する研究. 歯 学 $1996 ; 84: 68-73$.

8) Kordaß B, Rückert B, Stüttgen U, Zur Länge. Lage der interkondylarachse. Dtsch Zahnarztl Z 1997; 52: 6-9.
9）坂東永一, 中野雅徳, 藤村哲也, 西川啓介, 竹内久裕. 顎 機能の臨床的診査一MM-J I を用いて一. 補綴誌 1998; $42: 894-901$.

10）常磐 肇, 桑原洋助. 顎機能の臨床的診査一ナソヘキサ グラフを用いて一. 補綴誌 $1998 ; 42: 902-912$.

11）河野正司. 6 自由度顎運動測定装置 TRIMET を使って。 補綴誌 $1998 ； 42 ： 913-920$.

12) 中田 稔, 山崎要一, 早崎治明. 6 自由度顎運動測定器 の臨床への展開. 補綴誌 1998；42:921-927.

13）長谷川成男, 真柳昭紘. 6 自由度顎運動測定器のこと. 補綴誌 $1998 ； 42 ： 928-931$.

14）小川 匠, 重田優子, 安藤栄里子, 平井真也, 須磨真 由美, 平林里大ほか. 光位置測定方式 6 自由度顎運動 測定装置の開発と臨床応用の検討。補綴誌 $2006 ; 50$ ： 210-218.

15）内田貴之, 酒井 淳, 岡本康裕, 渡辺 官, 北川剛至, 會 田雅啓ほか. 超音波式 6 自由度䫈運動測定装 CMS-JAW の測定精度に関する研究。補綴誌 2008; $52: 350-359$.

16）丸山雅昭. 種々な下顎位における下顎の急速反復開閉口 運動に関する研究。補綴誌 $1973 ; 17: 308-322$.

17）佐藤克彦、咬合挙上および頭部の傾斜がタッピングポイ ントの分布状態に及ぼす影響について。補綴誌 1991 ； $35:$ 983-996.

18）尾松素樹, 溝上隆男. タッピング時の力がタッピング・ エリアの左右的位置に及ぼす影響に関する研究. 補綴誌 $1992 ; 36$ : 1141-1147.

19）蔵本 誠, 松山剛士，河野正司. タッピング運動時に 観察される頭部矢状面内協調運動。補綴誌 $1999 ; 43$ ： 575-581.

20）石井立人. 頭位および体位の側方傾斜に伴うヒトの外側 翼突筋下頭筋電図の応答。補綴誌 1994;38:363-367.

21）藤田直樹. 咀嚼筋緊張に関する筋電図学的研究. 補綴誌 $1973 ; 17: 259-274$.

22) Funakoshi M, Fujita N, Takehana S. Relations between occlusal interference and jaw muscle activities in response to changes in head position. J Dent Res 1976; 55: 684-690.

23）三塚影弘. 頭位の変化が咀嚼筋に与える影響に関する筋 電図学的研究. 歯学 $1977 ; 65: 200-229$.

24）渡辺 誠, 佐々木啓一, 稲井哲司, 鹿沼晶夫。緊張性頸 反射と EMGバイオフィードバックによる顎関節症患者 の診断. 顎機能誌 $1984 ; 2: 53-58$.

25）大前泰三，田中孝一，吉川健司，石垣尚一，赤西正光， 丸山剛郎。頭位の変化が頭頸部の筋の筋活性に及ぼす影 響について。補綴誌 $1990 ; 34: 1008-1014$.

26）佐藤康弘. 姿勢変化が咬合機能時の胸鎖乳突筋の活動に 及ぼす影響について。质誌 $1995 ; 62: 29-47$.

\author{
著者連絡先 : 小出 馨 \\ 于 951-8580 \\ 新潟県新潟市中央区浜浦町 1-8 \\ Tel: 025-267-1500 (内線 3301) \\ Fax: 025-265-5846 \\ E-mail: koide@ngt.ndu.ac.jp
}




\title{
Influence of Lateral Head Tilt on Mandibular Position
}

\author{
Yu Nakajima, DDS, PhD, Kaoru Koide, DDS, PhD, Itsuka Arakawa, DDS and Katsuyoshi Koide, DDS
}

Department of Removable Prosthodontics, The Nippon Dental University School of Life Dentistry at Niigata

Ann Jpn Prosthodont Soc 6: 300-308, 2014

\section{ABSTRACT}

Purpose: To examine the effect of lateral head tilt on mandibular position, we measured the positions of the condylar and incisal points in three dimensions after lateral tilting of the head. The relationship between head tilt angle and mandibular position was subsequently investigated.

Methods: Thirty healthy adults with normal occlusion and suffering no stomatognathic dysfunction were examined. An anterior jig was attached to the maxilla and a paraocclusal clutch was attached to the mandible. Left and right condylar and incisal points were measured by the Win Jaw System ${ }^{\circledast}$ at the following head tilt angles: $0^{\circ}, 5^{\circ}, 10^{\circ}, 15^{\circ}, 20^{\circ}, 25^{\circ}$, and $30^{\circ}$ (toward either side). Anteroposterior, horizontal, and vertical shifts of the condylar and incisal points from the corresponding reference positions were calculated at each tilt angle. Differences in head tilt angle were analyzed by one-way repeated measures ANOVA and Bonferroni's method.

Results: In the condylar points on the side of the flexed neck, anteroposterior, horizontal, and vertical shifts were not significantly different. Lateral head tilt caused significant anteroposterior and vertical shifts in the condylar points on the side of the extended neck, and the shift increased in line with head tilt angle of $10^{\circ}$ or more. Lateral head tilt caused significant anteroposterior and horizontal shift in the incisal points, and the shift increased in line with head tilt angle of $10^{\circ}$ or more.

Conclusions: Lateral head tilt causes a shift in the mandibular position which increases with increasing head tilt angle.

\section{Key words}

head posture, mandibular position, condylar point, incisal point,

3-dimensional jaw movement measurement device with six degrees of freedom 